However, the absence of direct correlation between O.D. units and the diphenylamine test remains to be explained, unless we assume the presence of two types of nucleic acid in PLRV, in analogy with data recently obtained on the coliphage T5 [10]. Further work is under' way with purer preparations of the virus and on the action of specific enzymes on the purified nucleic acid.

We thank Mrs. Renate Kaus for technical assistance.

Received July 30, 1973

1. Bode, O.: Angew. Bot. 36, 86 (1962)

2. Day, M. F., Zaitlin, M. : Phytopath. Z. 34, 83 (1959)

3. Peters, D.: Virology 31, 46 (1967)

4. Kojima, M., et al.: ibid. 39, 162 (1969)

5. Arai, K., et al.: Ann. Phytopath. Soc. Japan 35, 10 (1969)

6. Peters, D., Van Loon, L. C.: Virology 35, 597 (1968)

7. Sarkar, S.: Z. Naturforsch. (im Druck)

8. Burton, K.: Biochem. J. 62, 315 (1956)

9. Brandenburg, E.: Phytopath. Z. 43, 420 (1961)

10. Rosenkranz, H. S. : Nature 242, 327 (1973)

\section{Nachweis von Pheromonen bei Netzspinnen}

Rainer Blanke

Zoologisches Institut der Universität, Karlsruhe

Zwei Fragen wurden in letzter Zeit von Arachnologen immer wieder diskutiert: 1 . Wodurch werden bei vielen Netzspinnen, besonders Kreuzspinnen, die Männchen angelockt, die sich bei reifen Weibchen sammeln? 2. Können Spinnen riechen ? Vor allem die letzte Frage war sehr umstritten und wurde sowoh positiv als auch negativ beantwortet.

Lediglich bei den bodenlebenden Iycosiden sind bisher Pheromone nachgewiesen worden $[4,2,3]$. Hierbei handelte es sich allerdings um Kontaktpheromone [3], so daß ein echtes Riechen noch nicht bewiesen wurde. Bei Kreuzspinnen hatte man das Vorhandensein von Pheromonen schon mehrfach vermutet $[6,1]$

Bei Untersuchungen zum Sexualverhalten der tropischen Araneide Cyrtophora cicatrosa zeigte sich, daß etwa eine Woche nach der Reifehäutung des Weibchens eine starke Anlockung von Männchen aus der Umgebung erfolgte. In Versuchen mit Gazebeuteln, in denen die reifen Weibchen frei neben dem Netz eines anderen, nicht anlockend wirkenden Weibchens aufgehängt wurden, konnte ausgeschlossen werden, daß die Anlockung auf taktilem oder optischem Wege erfolgte. In weiteren Versuchen wurden den Männchen leere Beutel geboten, in de nen reife Weibchen $10 \mathrm{~h}$ lang gehalten worden waren. Die Tatsache, daß die Männchen auch von diesen Beuteln stark angezogen wurden, bewies eine Anlockung auf chemischem Wege. Die größte Entfernung, aus der ein Männchen auf ein geschlechtsreifes Weibchen im Beutel reagierte, betrug $50 \mathrm{~cm}$ Durch Aufstelien eines Ventilators hinter dem Beutel wurde ein Luftstrom in Richtung auf die Männchen zu erzeugt. Auf diese Weise konnte die anlockende Wirkung der Weibchen in hohem Maße verstärkt werden. Hieraus läßt sich einwandfrei ableiten, daß die Männchen die Weibchen bzw. die von ihnen abgeschiedenen Pheromone riechen können. Zwischen dem 10. und 20. Tag nach der Reifehäutung des Weibchens nimmt dessen anjockende Wirkung zu, um dann langsam wieder abzufallen. Hat das Weibchen mit einem Männchen kopuliert, ist zwei Tage nach der Kopulation keine anlockende Wirkung des Weibchens mehr festzustellen, $\mathrm{d}$ h. die Pheromon-Absonderung wird eingestellt. Da die Pheromone vom Weibchen auf die Unterlage übertragen werden, wirkt auch das Netz eines reifen Weibchens olfaktorisch anlockend.

Durch diese Ergebnisse werden auch die Befunde von Legendre [5] bestätigt, der bei Meta merianae sensorische Zellen fand die bei Männchen stärker entwickelt sind als bei Weibchen und die er als olfaktorische Organe anspricht.

Eingegangen am 6. August 1973

1. Blanke, R.: forma et functio 2,125 (1972)

2. Engelhardt, W.: Z. Morph. Ökol. Tiere 54, 219 (1964)

3. Hegdekar, B., Dondale: Canad. J. Zool. 47, 1 (1969)

4. Kolosvary, G.: Zool. Anz. 98, 307 (1932)

5. Legendre, R.: AnnIs. Sci. nat. Zool. 11, 141 (1958)

6. Millot, J.: Année biol. 22, 1 (1946)

\section{Artificial Induction of Lake Balls}

\section{S. Nakazawa}

Biology Department, Yamagata University, Yamagata, Japan A ball of Cladophora was first discovered by A. Sauter [1] in 1824 in the lake at Zell, Austria, and similar balls were later found in Europe, North America and Japan. The mechanism by which the algal filaments form a globular mass in nature has never been explained. The author carried out some experiments and succeeded in making balls of Cladophora filaments in a glass vessel.

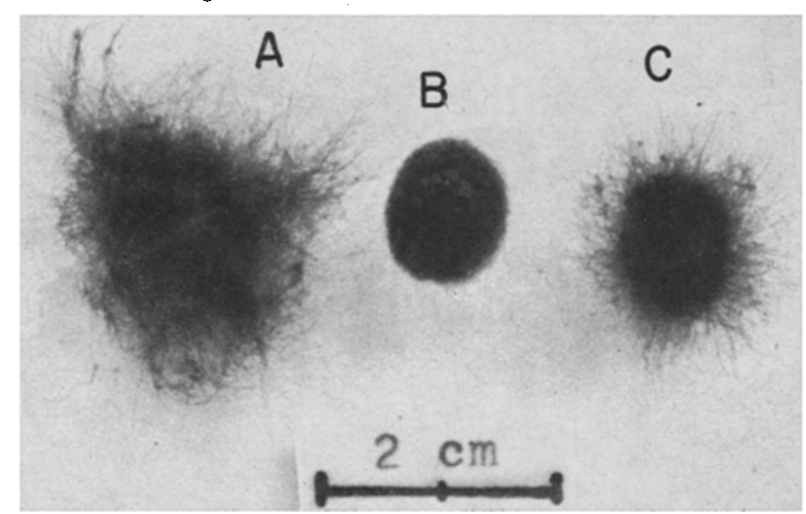

Fig. 1. Cladophora minima. A Filaments cultured in still water, $\mathrm{B}$ ball of filaments artificially induced, $\mathrm{C}$ ball with hairy new filaments growing on its surface

The material, Cladophora minima (Okada) Sakai f. minima Sakai [2], was collected from Lake Sakyo in the Aomori Prefecture, Japan. At first, it was cultured in still water containing Knop's solution at about $20 \%$ of the standard concentration, and the filaments grew in the form of a loosely twisted tuft (Fig. 1 A). This tuft with $5 \mathrm{mI}$ of the medium was put into a T-shaped glass vessel $25 \mathrm{~cm}$ in length and $1.5 \mathrm{~cm}$ in diameter which was set across the disk rotor of a rotary culture apparatus and rotated at 13 cycles a minute so that the medium with the filaments moved along the wall of the vessel from one end to the other; after 2 hours the filaments were assembled into a small ball. The ball was taken out and put into a 200-ml Erlenmeyer flask with $10 \mathrm{ml}$ of the same medium and shaken mechanically for 10 days in a reciprocating motion between $4 \mathrm{~cm}$ at 100 strokes a minute on a level plane, at $20^{\circ} \mathrm{C}$ under 150 lux white light. The algal ball then became very compact; it was next cultured in a glass vessel in the same medium under still conditions. In a week new filamentous growth occurred on the surface of the compact ball looking like hairs, in a month these new filaments grew much longer (Fig. 1 C). The ball was again shaken and a larger compact ball was obtained; this was again cultured in the still medium, and again the hairy filaments grew out. These experiments indicate that a mechanism for the development of a lake ball is the rolling of a coarse assemblage of Cladophoro filaments in shallow water moved by waves. If there is no such place, no lake ball will form. Such ideas based on natural observations have been published [3-5]. The present author has verified these speculations by the experiments reported here. The author is grateful to Mr. Tadashi Sugimoto who collected the material from the lake.

Received July 16, 1973

1. Sauter, A.: Flora 7, 209 (1824)

2. Sakai, Y.: Sci. Rep. Inst. Algol. Res. Fac. Sci. Hokkaido Univ. 5, 1 (1964)

3. Kanno, R. : Bull. Jap. Soc. Sci. Fish. 2, 217 (1934)

4. Nishimura, M. : Bot. Mag. Tokyo 37, 105 (1923)

5. Schröder, B.: Naturwissenschaften 8, 799 (1920)

\section{Demonstration of the Hybrid Origin of the Common Green Frog Rana esculenta $\mathrm{L}$.}

H. G. Tunner

I. Zoologisches Institut der Universität Wien

On the basis of his breeding experiments, Berger [1-3] considers $R$. esculenta a hybrid that arises permanently from crosses between $R$. vidibunda and $R$. lessonae or from back-crossing 